\title{
INTERVIEW
}

\section{Andrew DiRosa, MPA '02, Section Chief (Acting) of the Executive Intelligence Section of the Federal Bureau of Investigation}

\author{
By Rachel Brody and Joshua Nadas
}

\begin{abstract}
Mr. DiRosa obtained a Master's in Public Administration (MPA), with a focus on managing federal agencies, from The George Washington University in 2002. While at GWU, Andy served as editor of Policy Perspectives, and was awarded the Leadership Award and was inducted into the Pi Alpha Alpha public administration honor society. Andy obtained a BA from Old Dominion University (Norfolk, VA) in English and Political Science in 1987. While at ODU he was elected to two terms on the student senate.
\end{abstract}

Presently, Andy is the assistant section chief of the Executive Intelligence Section in the FBI's Directorate of Intelligence at FBI Headquarters. In this capacity he helps oversee daily operation of 24-hour units that prepare the daily intelligence briefing materials for the FBI Director, US Attorney General, and other senior executives. Andy has also worked in the FBI's Counterterrorism Division, as an intelligence analyst and supervisor, and in the FBI's training division and office of public affairs, as managing editor of the FBI Law Enforcement Bulletin, a widely read criminal justice journal. He authored book reviews and journal articles, including features on street gangs and the impact of the Second World War on US law enforcement. While in the Counterterrorism Division Andy served in an international intelligence cell at NATO headquarters in Brussels. Mr. DiRosa has also represented the FBI at bilateral intelligence exchanges with Canada and the United Kingdom. (Views expressed are those of Mr. DiRosa and do not necessarily reflect the views of the FBI.)

\section{Policy Perspectives: Did you always plan to go into public service?}

Yes. As a child I would go with my father to the central post office, in the federal building in downtown Norfolk, which to a small boy seemed like an especially large and grand building. Standing in it you get a sense of the permanence of the building, and that government plays an important and profound role in society. I studied political science and English as an undergraduate. After graduation, I applied to the FBI. It wasn't until around 2000 when I began my studies at GW, where I eventually earned my MPA.

\section{PP: Did getting your MPA help you in your career?}

It did. I had a fairly different experience than students who went directly from their undergraduate studies to their graduate work; I was working full time at the FBI when I attended GW. I had served as the managing editor of the FBI Law Enforcement Bulletin and had recently transferred to the FBI's national security divi- 
sion when I began my studies at GW.

What really helped is that graduate school gave me a great deal of confidence in the professional setting, especially to ask questions. When students go through a rigorous program like the one at GW they become confident in their ability to understand things. So, when you come across something in the workplace you don't understand, you're fairly sure it's not because you can't process the information. If there is something I have trouble following I routinely ask about it and the process often helps identify areas that require additional focus; colleagues sometimes say they had similar questions but did not ask because they thought they were missing something.

\section{PP: What made you decide to go to graduate school?}

One of the reasons I decided to go to graduate school was to develop skills useful as a supervisor or manager. While many managers in the FBI have advanced degrees I believe the MPA is fairly rare. The degree has helped me in a broad range of areas, from budgeting to recruiting, interviewing, and selecting employees to managing up and negotiating, to understanding interactions between the legislative and executive branches, to, as I've mentioned, building a strong foundation necessary for working with many different people in an array of situations.

$P P$ : As a successful public administrator, and GW alumni, what advice can you give students about how to pursue a career where they can take advantage of their skills from graduate school?

Being more than ten years out from graduation, I am a little bit removed from some of the terminology; however, tools like cost-benefit analysis and negotiation skills are things I use almost daily.

\section{PP: You were the Editor-in-Chief of}

\section{Policy Perspectives when you were at GW. How did being involved in publishing help your career?}

Being involved in the journal as a student forced me to manage my time very carefully, fittingly, using time management and task prioritization skills addressed in some of the first team-based exercises I was exposed to in the MPA program. Managing time and prioritizing tasks helped allow me to go to classes at night, while working and serving on the editorial board. I still use those time management skills today.

\section{PP: What could you say to graduate} students considering pursuing publication? Would you recommend it?

Yes. I got a lot out of my publication experience both for the FBI and while at school. In particular, publishing can really help to establish an author as an authority in a field. Additionally, being able to communicate clearly in writing, and having strong editing skills, should help advance any career.

\section{PP: Tell us why you like your job, and what challenges you face.}

I enjoy confronting new challenges every day. Presently, my responsibilities include overseeing two 24-hour teams, which poses some unique challenges for personnel and their managers. And as in any job it's fulfilling to work with other components of the organization to develop processes that achieve positive outcomes.

PP: Some students worry that a federal career is slow and un-stimulating. It sounds like your experience could not be further from that, can you talk to use about it?

I would really encourage students not to be dissuaded by the possibility of slow advancement within the federal government. I moved up fairly quickly, and found the pay and benefits at the FBI to be competitive. There also are built-in advantages to working for the government, such as strong benefit packages and stability, and a lot of 
the negative stereotypes about a federal career are not necessarily true. Like any organization, the federal government is made up of people, in my experience very dedicated public servants, and individuals can help shape their own careers.

PP: What would you say are the greatest challenges for people in public service going forward?

Inevitably, there will be constriction of financial resources available in federal budgets. Even in national security, where we have experienced sizeable increases in resources during the past ten years, there are natural cycles to the process, and going forward there are likely to be fewer resources available to do the same or even an expanding job.

Additionally, the recruiting and hiring process remains a constant challenge. It can be difficult to get the right kind of people, those who have strong academic and professional backgrounds, to consider careers in the government, particularly given traditional concerns about navigating the federal hiring process.
PP: What advice can you give to students studying Public Policy and Public Administration as they are working to find meaningful careers? Learn from and make the most of opportunities. My first job in the FBI was as a tour guide and although I envisioned being engaged in much different kinds of work, I tried to learn as much as I could from that experience. Though I moved on to other kinds of jobs within the Bureau, I still draw upon the wealth of history and organizational information I learned as a guide. I also became comfortable explaining and discussing FBI programs and initiatives with groups, something I have drawn upon throughout my career in outreach efforts within and outside the FBI.

Studying Public Policy and Public Administration gives you a very strong general background, and it helps provide a confidence to respond to any situation. That ends up being a very important lesson and it's one we largely teach ourselves. 